\title{
Improved Approach to Behavioral Theory for Predicting the Preferred Capital Structure in Commercial Organizations in the Regions of Armenia
}

\author{
Khachatur Baboyan \\ Institute of Economics after M. Qotanyan \\ National Academy of Sciences of the Republic of Armenia \\ Yerevan, Armenia \\ xach-baboyan@mail.ru
}

\begin{abstract}
Commercial organizations should, in line with the principles of financial management, attach primary importance to the issues of formation of capital structure, establishment of the structure preferred and, as a new solution, to the issues of prediction. As financial assets are predominantly managed by the banking system, the problem of formation of the preferred capital structure in the commercial organizations of the Republic of Armenia is related to the control of the debt burden. In the professional literature and within the scope of practically applicable approaches to financial management, there are still no criteria for the effective control of capital structure and the determination of a preferred structure. Conditioned by not fully effective functioning of the financial market, commercial organizations seek to address their strategic problems in the process of capital formation through the banking system, which - in the conditions of high interest rates - gives rise to various problems which may worsen the financial situation in the future. At the same time, in line with the development of the IT sector, there occurs a strong need for such prediction approaches which enable acquisition of the desired information online. In this article we primarily aimed to propose such an effective solution among the methods of improvement of the financial management of commercial organizations.
\end{abstract}

Keywords-model, variable, range, structure, theory, capital, organization, neural network, optimum.

\section{INTRODUCTION}

The first theory on the formation of capital structure was given by J. Williams in the 1940-1950s. [1]

Their theories on the capital structure of organization were put forward by D. Durand [2], F. Modigliani and M. Miller [3], who put the fundamentals for the financial management of capital structure.

An Armenian researcher A. V. Arakelyan offerred partial individual solutions to the issues of establishment of a favorable capital structure [4] and valuation of capital [5].

Within the scope this article, we made an emphasys on the signaling models significant in the process of capital structure optimization, which convey the investors necessary signals on the capital market. In this regard, Rossi's[6] approach is well-known, according to which the top management team of the organization may use capital structure as a signal for the external investors on the basis of which the latter receive information on the perspectives of the development of the organization. The model proposed by this researcher enables us to conclude that the increase in debt burden of the organization will be evaluated as an important signal of financial stability of the organization and an increase in expected cash flows, which will make it possible to service its debt obligations. In our opinion, the increase in the debt burden of the organization cannot be infinite, it must be within the permissible limits of the predetermined financial risk.

In order to receive signals for distribution of asymmetric information on capital structure of the organization, $\mathrm{H}$. Leland and D. Pyle proposed their model, which highlights the following conclusions [7]:

- the investor's desire to invest its own assets in the investment program is viewed by the financial market as a positive signal;

- the higher is the risk of the investment program, the lower is the level of debt burden.

In fact, growth of the debt burden of the organization is viewed in the market as a positive signal for the quality of investment programs, as well as for the desirable level of financial stability of the organization.

The signaling theory, factually, like the hierarchical theory, is based on the persumption of availability of asymmetric information in the capital market. However, if the hierarchical theory emphasizes the negative connection between the financial leverage and profitability of the organization, the signaling models demonstrate that the higher is the organization's profitability, the higher is the value of the financial leverage. 
In line with the scientific and technological progress, at the present stage, one of the preferred areas of research is the construction of dynamic signaling models, as well as the development of such complex models that make it possible to combine the essential principles of individual theories of the capital structure.

D. Kahneman and A. Tversky proposed the theory of perspectives and substantiated that manifestation of negative behaviour of an individual results from misunderstanding and misevaluation of information [8].

Within the scope of the behavioral theory of capital structure, three main directions have emerged. They are: Market timing theory, information cascade theory, theory of the influence of top management team characteristics.

The most well-founded of the above-mentioned theories is the market timing theory, which is based on the financial decisions made on the state of the financial market [9].

On the basis of the data of G7, A. Mahajan and S. Tartaroglu demonstrated the inverse dependence of statistical significance between the market and balance sheet values of financial leverage and assets [10].

As a result, they found out that the capital structure in the large organizations of the United States, France, Canada and the United Kingdom changes in the case of additional issue of securities; the impact of adherence to the capital market is short-term and is neutralized in a maximum of five years.

The theory of information cascades has been studied by S. Bikhchandani, D. Hirshleifer and I. Welch [11]. ${ }^{1}$. According to them, an optimal stategy for demonstration of an indvidual's behavour is the recurrence of actions or decisions of his or her predecessors who appear in such situations irrespective of the personal information they obtain.

Within the framework of information cascade theory, the formation of capital structure of the organization is carried out by assessing the impact of the branch debt burden as a factor (from the statistical indicators - the median, the mean) on the financial leverage of the organization.

The theory of the influence of top management team (TMT) characteristics is based on the assumption that when making decisions on the formation of capital structure during the management process, there may be behavioral deviations under the influence of internal and external factors. In particular, the research made by L. Barros and A. Silveira revealed that overconfidence of the top management has a direct influence on the organization's financial leverage [12].

Both in theoretical and practical terms, all three directions of the behavioral theory of capital structure are important, however, in order to improve the efficiency of financial decision-making, it is appropriate to combine them with the synthesis of several other approaches.

Given the importance of the issue and the situation caused by Covid-19, we developed and offer an approach to predicting own current assets relevant to capital structure of the organization.
It should be noted that Armenian researchers $\mathrm{K}$. Hovhannisyan[13], M. Matevosyan and A. Matevosyan[14], and A. Mirzoyan[15] also addressed the issues concerning the assessment of security in own current assets from the perspective of another relationship within the scope of financial management, by offering certain solutions based on their own research experience.

It should also be noted that within the scope of the anticrisis management directed to overcome the economic consequences of Covid-19, each commercial organization needs to revise the requirement for security in their own current assets and find solutions to cover the existing deficit. The description of the model developed within the scope of our approach is presented below.

\section{MAIN PART}

\section{Step 1. Main Variables of the Neural Network}

In order to predict the variable $\mathrm{Y}_{1}$ (the index of security in own current assets in percentage) from the variables $\mathrm{P}_{1}-\mathrm{P}_{5}$ ( $\mathrm{P}_{1}$ is the share of equity in total liabilities; $\mathrm{P}_{2}$ is the share of long-term loans and borrowings in total liabilities; $\mathrm{P}_{3}$ is the share of short-term loans and borrowings in total liabilities; $\mathrm{P}_{4}$ is the share of commercial and other accounts payable in total liabilities; $\mathrm{P}_{5}$ is the share of other stable liabilities in total liabilities), a deep neural network is formed using TensorFlow package, which has the following structure: ' 5 $5-10-20-10-5-1$. Thus, there are five layers placed between five input neurons and one output neuron, the neural composition of each of which is presented above.

The activation function of each layer is sigmoid; the value of the output signal of the $\mathrm{k}^{\text {th }}$ neuron placed in the middle layer is determined by:

$$
\phi_{k}(x)=\frac{1}{1+e^{-x}}
$$

where:

$$
x=\sum_{i=1}^{m} w_{k j} x_{j},
$$

$\mathrm{m}$ is the number of neurons in the proceeding "input" layer, $\mathrm{X}_{\mathrm{j}}$ is the output signal of the $\mathrm{j}^{\text {th }}$ neuron in that layer, $w_{k j}$ is the weight corresponding to $\mathrm{j}->\mathrm{k}$ connection.

During the training, the problem of weight optimization is solved through the gradient reduction algorithm[16]. The model built and optimized on the basis of the training data calculates the loss function during the program's activity; as a loss function we chose Mean Square Error.

The goal of the gradient reduction method is to minimize the loss function. The test data do not participate in model optimization process, that is in reducing the loss function. However, after each iteration, the test data are entered into the improved model, and the output result of the model is therefore compared with the relevant value of the test data. Thus, the applicability of the model for other data besides the training ones is also checked.

\section{Step 2.1. Input Data:}

\footnotetext{
${ }^{1}$ Bikhchandani S. Learning from the Behavior of Others: Conformity, Fads, and Informational Cascades / S.
}

Bikhchandani, D. Hirshleifer, I. Welch // The Journal of Economic Perspectives. 1998. Vol. 12. No 3. pp. 151-170. 
TABLE I. STATISTICAL INFORMATION ON THE MODEL TRAINING PROCESS

\begin{tabular}{|c|c|c|c|c|c|c|c|c|}
\hline $\mathrm{N}$ & $\mathbf{P}_{1}$ & $\mathbf{P}_{2}$ & $\mathbf{P}_{3}$ & $\mathbf{P}_{4}$ & $\mathbf{P}_{5}$ & $\mathbf{Y}_{1}$ & $\mathbf{Y}_{1}$ Predicted & $\begin{array}{l}\text { RelAbsErrY1 in } \\
\% \mathrm{~s}\end{array}$ \\
\hline 1 & 2 & 3 & 4 & 5 & 6 & 7 & 8 & 9 \\
\hline 41 & 23.07002 & 60.31283 & 12.15007 & 4.112093 & 0.35499 & 67.21547 & 67.2122421 & 0.004795895 \\
\hline 14 & 47.15995 & 38.69142 & 1.04204 & 6.90921 & 6.197381 & 76.52458 & 76.5237503 & 0.00108002 \\
\hline 78 & 19.19024 & 29.08026 & 14.66016 & 29.81476 & 3.689752 & 28.05721 & 28.0571747 & 0.000112069 \\
\hline 65 & 75.59877 & 10.54795 & 4.344825 & 8.788 & 0.720452 & 74.18181 & 74.1796875 & 0.002858301 \\
\hline 1 & 16.82744 & 64.64867 & 0.354777 & 17.60944 & 0.207236 & 73.46364 & 73.4609985 & 0.003593413 \\
\hline 22 & 75.59877 & 10.54795 & 4.344825 & 8.788 & 0.720452 & 74.18181 & 74.1796875 & 0.002858301 \\
\hline 68 & 26.84058 & 9.335299 & 24.88928 & 14.26008 & 24.4285 & 22.59535 & 22.5908279 & 0.020023992 \\
\hline 35 & 19.19024 & 29.08026 & 14.66016 & 29.81476 & 3.689752 & 28.05721 & 28.0571747 & 0.000112069 \\
\hline 39 & 16.82744 & 64.64867 & 0.354777 & 17.60944 & 0.207236 & 73.46364 & 73.4609985 & 0.003593413 \\
\hline 42 & 73.14113 & 4.838227 & 0.574367 & 21.21085 & 0.019311 & 39.66018 & 39.6554947 & 0.011826223 \\
\hline $\mathbf{0}$ & 28.61358 & 57.93813 & 0.362885 & 12.6426 & 0.192007 & 82.72778 & 82.7251129 & 0.003229848 \\
\hline 61 & 30.39237 & 55.34332 & 6.594781 & 7.651183 & 0.002048 & 74.3585 & 74.3505173 & 0.010734667 \\
\hline 3 & 73.14113 & 4.838227 & 0.574367 & 21.21085 & 0.019311 & 39.66018 & 39.6554947 & 0.011826223 \\
\hline
\end{tabular}

The first give columns of Table 1 show the structural components of capital of a particular organization; $\mathrm{P}_{1}-\mathrm{P}_{5}$ are the input variables of the first layer of neural network. The corresponding real target $Y_{1}$ variable is presented in the $6^{\text {th }}$ column, and the predicted outputs of the model obtained as a result of the training process are presented in $7^{\text {th }}$ column.
Column 8 shows the absolute values of the relative error in percentage.

Step 2.2. Test results in respect of the output indicator of $Y_{1}$ :

TABLE II. TEST RESULTS OF THE MODEL IN RESPECT OF $\mathrm{Y}_{1}$

\begin{tabular}{|c|c|c|c|c|c|c|c|c|}
\hline $\mathrm{N}$ & $\mathrm{P}_{1}$ & $\mathrm{P}_{2}$ & $\mathrm{P}_{3}$ & $\mathrm{P}_{4}$ & $\mathrm{P}_{5}$ & $\mathrm{Y}_{1}$ & $\mathrm{Y}_{1}$ predicted & RelAbsErrY1 in \%s \\
\hline 1 & 2 & 3 & 4 & 5 & 6 & 7 & 8 & 9 \\
\hline 25 & 26.8406 & 9.3353 & 24.889 & 14.2601 & 24.429 & 22.6 & 22.5908279 & 0.020023992 \\
\hline 2 & 23.07 & 60.313 & 12.15 & 4.11209 & 0.355 & 67.22 & 67.2122421 & 0.004795895 \\
\hline 54 & 47.1599 & 38.691 & 1.042 & 6.90921 & 6.1974 & 76.52 & 76.5237503 & 0.00108002 \\
\hline 19 & 30.3924 & 55.343 & 6.5948 & 7.65118 & 0.002 & 74.36 & 74.3505173 & 0.010734667 \\
\hline
\end{tabular}

In relation with $\mathrm{Y} 1$, the test data, which are not involved in the weight optimization process, are separated from the main data set. Table 2, where the application results on the test data of the model trained in respect of $Y_{1}$ are reported, shows that the maximum relative error of the model is $0.02 \%$.
Step 2.3. Prediction results in respect of the output indicator of $Y_{1}$. In the process of improvement of the behavioral theory of capital structure, the data generated in respect of $Y_{1}$ on randomly chosen commercial organizations of the Russian Federation tested on the basis of our approach are presented in Table 3.

TABLE III. PREDICTIONS FOR RANDOMLY TESTED COMMERCIAL ORGANIZATIONS

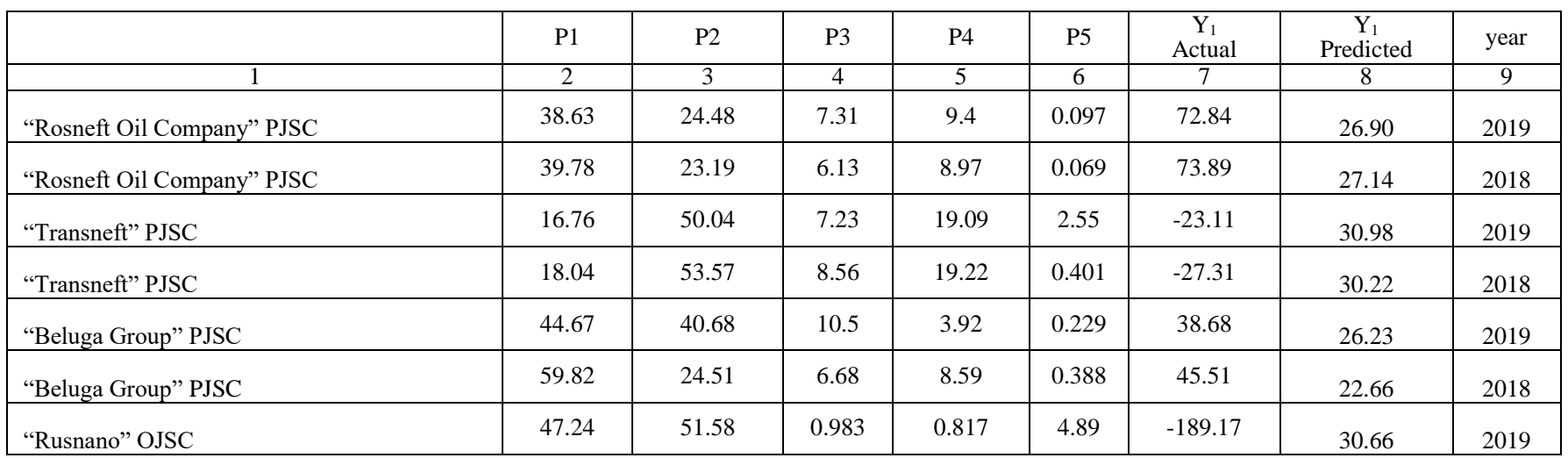




\begin{tabular}{|l|c|c|c|c|c|c|c|c|}
\hline "Rusnano" OJSC & 53.64 & 15.09 & 11.39 & 1.79 & 4.29 & -121.43 & 23.56 & 2018 \\
\hline “Magnit P”JSC & 19.87 & 12.61 & 6.80 & 17.04 & 7.82 & -19.51 & 29.44 & 2019 \\
\hline "Magnit” PJSC & 24.05 & 10.61 & 8.02 & 14.84 & 7.91 & -20.24 & 28.38 & 2018 \\
\hline "LUKoil Oil Company PJSC" PJSC & 71.27 & 8.43 & 2.81 & 8.44 & 0.46 & 39.18 & 21.45 & 2019 \\
\hline "LUKoil Oil Company PJSC" PJSC & 66.81 & 7.11 & 2.19 & 10.22 & 2.84 & 22.29 & 21.93 & 2018 \\
\hline “TransContainer" PJSC & 58.46 & 23.82 & 4.93 & 10.34 & 9 & 26.25 & 23.03 & 2019 \\
\hline “TransContainer" PJSC & 57.31 & 23.67 & 3.79 & 12.33 & 0.026 & 24.45 & 23.17 & 2018 \\
\hline
\end{tabular}

On the basis of the model built, according to the data referred to in table 3 , correct solutions have been predicted for those organizations where cases of not being secured by own current assets have been observed, namely, for "Transneft" PJSC, "Rusnano" OJSC and "Magnit" PJSC. It fully complies with the theoretical and practical decisions rendered within the scope of the conceptual provisions of financial management.

Step 2.4. Input Data: Test results in respect of the output indicator of Y2 (the maximum relative error of the model is $0.02 \%)$.

According to the approach proposed in this article for the improvement of the behavioral theory of capital structure, the data from randomly chosen commercial organizations of the Russian Federation have been tasted. Based on the prediction model, improvement has been recorded in case of all observations in relation to the output indicator of Y2. Thus, the prediction model built unequivocally envisages a positive adjustment of the output indicator of Y2. It is obvious that the problem of securing one's own current assets from the point of view of priority in the process of developing financial policy should be addressed within the scope of determining the component areas of the financial position. If the solutions predicted in respect of Y1 unequivocally meet the requirements of the conceptual provisions of financial management, the solutions envisaged in respect of Y2 need to be theoretically and practically assessed from the point of view of expediency of decisions to increase the equity and long-term liabilities and the existing opportunities for their involvement.

TABLE IV. TEST RESUlTS OF THE MODEL IN RESPECT OF $\mathrm{Y}_{2}$

\begin{tabular}{|c|c|c|c|c|c|c|c|c|}
\hline $\mathrm{N}$ & $\mathrm{P}_{1}$ & $\mathrm{P}_{2}$ & $\mathrm{P}_{3}$ & $\mathrm{P}_{4}$ & $\mathrm{P}_{5}$ & $\mathrm{Y}_{2}$ & $\mathrm{Y}_{2}$ predicted & RelAbsErrY1 in \%s \\
\hline 1 & 2 & 3 & 4 & 5 & 6 & 7 & 8 \\
\hline 0 & 28.61358 & 57.93813 & 0.362885 & 12.6426 & 0.192007 & 220.9136 & 220.00034 & 0.413395755 \\
\hline 35 & 19.19024 & 29.08026 & 14.66016 & 29.81476 & 3.689752 & 97.88257 & 97.80921 \\
\hline 39 & 16.82744 & 64.64867 & 0.354777 & 17.60944 & 0.207236 & 298.9529 & 297.70508 & 0.074944091 \\
\hline 61 & 30.39237 & 55.34332 & 6.594781 & 7.651183 & 0.002048 & 135.9493 & 135.6083 & 0.250807417 \\
\hline
\end{tabular}

Step 2.5. We have predicted the structure of the main and essential sources of capital formation in accordance with the actual values of $\mathrm{Y} 1$ and $\mathrm{Y} 2$.

By using the above-mentioned model, the prediction of Y1 and Y2 variables shows that we can get the same (Y1, Y2) pair in the case of significantly different (P1 - P5) quintiles. That is why the search for the (P1 - P5) quintiles corresponding to the given $\mathrm{Y} 1, \mathrm{Y} 2$ pair is performed by the method of solving the inverse problem. For each $\mathrm{P}_{1}-\mathrm{P}_{5}$ variables a set of values are selected (in this case the range of minimum and maximum values of each variable is divided into 10 equal segments and the values of the endpoints of the segments are taken; for each variable -11 in total), and at the input of the model predicting the (Y1, Y2) variables, all the possible quintiles consisting of the elements of these sets are given, $11^{5}=161051$ in total. The results of the predicition, from which the desirable $\left(\mathrm{P}_{1}-\mathrm{P}_{5}\right)$ quintiles corresponding to $(\mathrm{Y} 1, \mathrm{Y} 2)$ variables are filtered, are obtained based on the data of 45 industrial, commercial organizations studied on the basis of the values of the output variables of (Y1, Y2) pair.

TABLE V. RESEARCH EXAMPLES BASED ON THE VALUES OF THE OUTPUT VARIABLES OF THE PAIR (Y1, Y2)

\begin{tabular}{|c|c|c|c|c|c|c|c|}
\hline & $\mathbf{P}_{1}$ & $\mathbf{P}_{2}$ & $\mathbf{P}_{3}$ & $\mathbf{P}_{4}$ & $\mathbf{P}_{5}$ & $\mathbf{Y}_{1}$ & $Y_{2}$ \\
\hline 1 & 16.82744 & 28.76241 & 12.62203 & 6.68236 & 17.10056 & 31.35379 & 200.8766 \\
\hline 2 & 16.82744 & 40.7245 & 10.16858 & 22.10396 & 7.329984 & 31.34174 & 200.485 \\
\hline 3 & 22.70457 & 10.81927 & 2.808227 & 14.39316 & 19.54321 & 31.85463 & 200.9041 \\
\hline 4 & 22.70457 & 22.78136 & 0.354777 & 29.81476 & 9.772629 & 31.84284 & 200.5125 \\
\hline 5 & 22.70457 & 58.66763 & 17.52893 & 11.82289 & 9.772629 & 31.43298 & 200.0472 \\
\hline 6 & 22.70457 & 64.64867 & 22.43583 & 4.112093 & 12.21527 & 31.1581 & 200.9983 \\
\hline 7 & 28.5817 & 28.76241 & 10.16858 & 4.112093 & 21.98586 & 31.94391 & 200.4658 \\
\hline 8 & 28.5817 & 40.7245 & 7.715127 & 19.5337 & 12.21527 & 31.93216 & 200.0746 \\
\hline 9 & 28.5817 & 58.66763 & 10.16858 & 27.2445 & 4.887338 & 31.65106 & 200.634 \\
\hline 10 & 34.45884 & 22.78136 & 0.354777 & 24.67423 & 17.10056 & 31.50305 & 200.0963 \\
\hline
\end{tabular}




\begin{tabular}{|l|c|c|c|c|c|c|c|}
\hline $\mathbf{1 1}$ & 40.33597 & 46.70554 & 12.62203 & 6.68236 & 21.98586 & 31.32058 & 200.6091 \\
\hline $\mathbf{1 2}$ & 40.33597 & 58.66763 & 10.16858 & 22.10396 & 12.21527 & 31.30852 & 200.2178 \\
\hline $\mathbf{1 3}$ & 46.2131 & 28.76241 & 2.808227 & 14.39316 & 24.4285 & 31.82211 & 200.6365 \\
\hline $\mathbf{1 4}$ & 46.2131 & 40.7245 & 0.354777 & 29.81476 & 14.65792 & 31.81031 & 200.2452 \\
\hline $\mathbf{1 5}$ & 52.09024 & 64.64867 & 12.62203 & 11.82289 & 19.54321 & 31.63017 & 200.7581 \\
\hline $\mathbf{1 6}$ & 57.96737 & 46.70554 & 5.261677 & 16.96343 & 24.4285 & 31.19557 & 200.7798 \\
\hline $\mathbf{1 7}$ & 69.72164 & 64.64867 & 5.261677 & 22.10396 & 21.98586 & 31.50671 & 200.9288 \\
\hline
\end{tabular}

The starting point is the following: $\mathrm{Y}_{1} \varepsilon[30 ; 31], \mathrm{Y}_{2} \varepsilon$ [200;201]. This kind of application of the model makes it possible to control the $\mathrm{P}_{1}-\mathrm{P}_{5}$ variables in order to have the desirable (Y1, Y2) pair. It should be noted that the prediction model makes it possible to periodically review the ranges of $\left(\mathrm{Y}_{1}, \mathrm{Y}_{2}\right)$ pair, where necessary, which enhances the dynamic nature of the model further. The results proposed by the inverse prediction model for the commercial organizations of the Russian Federation built by a randomly selected $\left(\mathrm{Y}_{1}, \mathrm{Y}_{2}\right)$ pair are provided below. The following condition has been accepted for $\left(\mathrm{Y}_{1}, \mathrm{Y}_{2}\right)$ pair: $\mathrm{y} 1>=20.173225$ y2 $>=$ 34.5452637

TABLE VI. RANGES OF THE PREFERREd CAPITAL STRUCTURE Proposed FOR THE $\left(\mathrm{P}_{1}-\mathrm{P}_{5}\right)$ QUiNTILES IN THE COMMERCIAL ORGANIZATIONS OF THE RUSSIAN FEDERATION STUDIED

\begin{tabular}{|c|c|c|c|c|c|c|}
\hline $\begin{array}{l}\text { Name of the } \\
\text { Organization }\end{array}$ & & $\begin{array}{l}((\text { Total } \\
\text { Equity)/(Balance } \\
\text { Sheet7 Total }))^{*} \\
100 \%\end{array}$ & $\begin{array}{l}((\text { Long-Term Financial } \\
\text { Liabilities }) /(\text { Balance } \\
\text { Sheet Total) }) * 100 /\end{array}$ & $\begin{array}{l}((\text { Short-Term } \\
\text { Borrowings and Loans } \\
\text { Received; Hedging } \\
\text { Tools)/(Balance Sheet } \\
\text { Total) }) * 100\end{array}$ & $\begin{array}{lr}((\text { Operational } & \text { and } \\
\text { Other } & \text { Current } \\
\text { Accounts } & \text { Payable }) ~ / \\
(\text { Balance } & \text { Sheet } \\
\text { Total }))^{*} 100 & \end{array}$ & $\begin{array}{l}\text { ((Other } \\
\text { Current } \\
\text { Liabilities }) /( \\
\text { Balance } \\
\text { Sheet } \\
\text { Total }))^{*} 100\end{array}$ \\
\hline & & $\mathrm{P}_{1}$ & $\mathrm{P}_{2}$ & P3 & P4 & $\mathrm{P}_{5}$ \\
\hline \multirow{6}{*}{$\begin{array}{l}\text { "Rosneft } \quad \text { Oil } \\
\text { Company" PJSC } \\
2019\end{array}$} & & \multicolumn{5}{|c|}{ Actual } \\
\hline & & 38.63 & 24.48 & 7.31 & 9.4 & 0.097 \\
\hline & & \multicolumn{5}{|c|}{ Predicted } \\
\hline & Max & 63.84 & 64.65 & 10.17 & 22.10 & 14.66 \\
\hline & Average & 39.94 & 51.09 & 2.48 & 9.51 & 6.27 \\
\hline & $\min$ & 16.827 & 22.781 & 0.355 & 4.112 & 0.002 \\
\hline \multirow{6}{*}{$\begin{array}{l}\text { "Rosneft } \quad \text { Oil } \\
\text { Company" PJSC } \\
2018\end{array}$} & & \multicolumn{5}{|c|}{ Actual } \\
\hline & & 38.63 & 24.48 & 7.31 & 9.4 & 0.097 \\
\hline & & \multicolumn{5}{|c|}{ Predicted } \\
\hline & Max & 69.72 & 64.65 & 10.17 & 19.53 & 14.66 \\
\hline & Average & 39.75 & 51.69 & 2.89 & 8.65 & 5.86 \\
\hline & $\min$ & 22.705 & 28.762 & 0.355 & 4.112 & 0.002 \\
\hline \multirow{6}{*}{$\begin{array}{l}\text { “Transneft" PJSC } \\
2019\end{array}$} & & \multicolumn{5}{|c|}{ Actual } \\
\hline & & 16.76 & 50.04 & 7.23 & 19.09 & 2.55 \\
\hline & & \multicolumn{5}{|c|}{ Predicted } \\
\hline & Max & 52.09 & 64.65 & 19.98 & 29.81 & 24.43 \\
\hline & Average & 26.32 & 52.72 & 5.82 & 18.82 & 19.87 \\
\hline & $\min$ & 16.83 & 22.78 & 0.35 & 4.11 & 7.33 \\
\hline \multirow{6}{*}{$\begin{array}{l}\text { “Transneft" PJSC } \\
2018\end{array}$} & & \multicolumn{5}{|c|}{ Actual } \\
\hline & & 18.04 & 53.57 & 8.56 & 19.22 & 0.401 \\
\hline & & \multicolumn{5}{|c|}{ Predicted } \\
\hline & $\max$ & 52.09 & 64.65 & 19.98 & 29.81 & 24.43 \\
\hline & average & 25.48 & 53.07 & 6.19 & 20.15 & 20.50 \\
\hline & $\min$ & 16.83 & 22.78 & 0.35 & 4.11 & 7.33 \\
\hline \multirow{6}{*}{$\begin{array}{l}\text { "Beluga Group" } \\
\text { PJSC } \\
2019\end{array}$} & & \multicolumn{5}{|c|}{ Actual } \\
\hline & & 44.67 & 40.68 & 10.5 & 3.92 & 0.229 \\
\hline & & \multicolumn{5}{|c|}{ Predicted } \\
\hline & $\max$ & 40.34 & 64.65 & 19.98 & 29.81 & 24.43 \\
\hline & average & 21.79 & 55.26 & 10.94 & 24.50 & 22.63 \\
\hline & $\min$ & 16.83 & 22.78 & 0.35 & 6.68 & 14.66 \\
\hline \multirow{6}{*}{$\begin{array}{l}\text { "Beluga Group" } \\
\text { PJSC } \\
2018\end{array}$} & & \multicolumn{5}{|c|}{ Actual } \\
\hline & & 59.82 & 24.51 & 6.68 & 8.59 & 0.388 \\
\hline & & \multicolumn{5}{|c|}{ Predicted } \\
\hline & $\max$ & 22.70 & 64.65 & 22.44 & 29.81 & 24.43 \\
\hline & average & 18.09 & 60.80 & 16.19 & 27.49 & 23.96 \\
\hline & $\min$ & 16.83 & 46.71 & 10.17 & 19.53 & 21.99 \\
\hline \multirow{6}{*}{$\begin{array}{l}\text { "RUSNANO" } \\
\text { OJSC } \\
2019\end{array}$} & & \multicolumn{5}{|c|}{ Actual } \\
\hline & & 47.24 & 51.58 & 0.983 & 0.817 & 4.89 \\
\hline & & \multicolumn{5}{|c|}{ Predicted } \\
\hline & $\max$ & 40.34 & 64.65 & 12.62 & 29.81 & 24.43 \\
\hline & average & 20.73 & 59.51 & 3.13 & 21.84 & 22.19 \\
\hline & $\min$ & 16.83 & 40.72 & 0.35 & 4.11 & 12.22 \\
\hline \multirow{4}{*}{$\begin{array}{l}\text { "RUSNANO” } \\
\text { OJSC } \\
2018\end{array}$} & & & & Actual & & \\
\hline & & 53.64 & 15.09 & 11.39 & 1.79 & 4.29 \\
\hline & & & & Predicted & & \\
\hline & $\max$ & 40.34 & 64.65 & 24.89 & 29.81 & 24.43 \\
\hline
\end{tabular}




\begin{tabular}{|c|c|c|c|c|c|c|}
\hline & average & 23.43 & 52.13 & 18.77 & 24.41 & 22.31 \\
\hline & $\min$ & 16.83 & 22.78 & 7.72 & 11.82 & 17.10 \\
\hline \multirow{6}{*}{$\begin{array}{l}\text { “Magnit” PJSC } \\
2019\end{array}$} & & \multicolumn{5}{|c|}{ Actual } \\
\hline & & 19.87 & 12.61 & 6.80 & 17.04 & 7.82 \\
\hline & & \multicolumn{5}{|c|}{ Predicted } \\
\hline & $\max$ & 75.60 & 64.65 & 24.89 & 29.81 & 24.43 \\
\hline & average & 34.20 & 41.72 & 10.87 & 18.80 & 17.52 \\
\hline & $\min$ & 16.83 & 4.84 & 0.35 & 4.11 & 2.44 \\
\hline \multirow{6}{*}{$\begin{array}{l}\text { "Magnit” PJSC } \\
2018\end{array}$} & & \multicolumn{5}{|c|}{ Actual } \\
\hline & & 24.05 & 10.61 & 8.02 & 14.84 & 7.91 \\
\hline & & \multicolumn{5}{|c|}{ Predicted } \\
\hline & $\max$ & 75.60 & 64.65 & 24.89 & 29.81 & 24.43 \\
\hline & average & 75.60 & 58.67 & 2.81 & 29.81 & 24.43 \\
\hline & $\min$ & 16.83 & 4.84 & 0.35 & 4.11 & 4.89 \\
\hline \multirow{6}{*}{$\begin{array}{lr}\text { "LUKoil } & \text { Oil } \\
\text { Company } & \text { PJSC" } \\
\text { PJSC } & \\
2019 & \end{array}$} & & \multicolumn{5}{|c|}{ Actual } \\
\hline & & 71.27 & 8.43 & 2.81 & 8.44 & 0.46 \\
\hline & & \multicolumn{5}{|c|}{ Predicted } \\
\hline & $\max$ & 22.70 & 64.65 & 19.98 & 29.81 & 24.43 \\
\hline & average & 17.36 & 61.93 & 17.75 & 28.65 & 24.21 \\
\hline & $\min$ & 16.83 & 52.69 & 15.08 & 24.67 & 21.99 \\
\hline \multirow{6}{*}{$\begin{array}{lr}\text { "LUKoil } & \text { Oil } \\
\text { Company } & \text { PJSC" } \\
\text { PJSC } & \\
2018 & \end{array}$} & & \multicolumn{5}{|c|}{ Actual } \\
\hline & & 66.81 & 7.11 & 2.19 & 10.22 & 2.84 \\
\hline & & \multicolumn{5}{|c|}{ Predicted } \\
\hline & $\max$ & 28.58 & 64.65 & 22.44 & 29.81 & 24.43 \\
\hline & average & 18.24 & 61.54 & 18.02 & 28.17 & 24.14 \\
\hline & $\min$ & 16.83 & 46.71 & 12.62 & 22.10 & 21.99 \\
\hline \multirow{6}{*}{$\begin{array}{l}\text { "TransContainer" } \\
\text { PJSC } 2019\end{array}$} & & \multicolumn{5}{|c|}{ Actual } \\
\hline & & 58.46 & 23.82 & 4.93 & 10.34 & 0.0019 \\
\hline & & \multicolumn{5}{|c|}{ Predicted } \\
\hline & $\max$ & 28.58 & 64.65 & 19.98 & 29.81 & 24.43 \\
\hline & average & 18.27 & 61.48 & 15.38 & 27.56 & 23.83 \\
\hline & $\min$ & 16.83 & 46.71 & 10.17 & 16.96 & 19.54 \\
\hline \multirow{6}{*}{$\begin{array}{l}\text { "TransContainer" } \\
\text { PJSC } \\
2018\end{array}$} & & \multicolumn{5}{|c|}{ Actual } \\
\hline & & 57.31 & 23.67 & 3.79 & 12.33 & 0.026 \\
\hline & & \multicolumn{5}{|c|}{ Predicted } \\
\hline & $\max$ & 28.58 & 64.65 & 19.98 & 29.81 & 24.43 \\
\hline & average & 18.30 & 61.52 & 14.80 & 28.00 & 23.82 \\
\hline & $\min$ & 16.83 & 46.71 & 10.17 & 22.10 & 19.54 \\
\hline
\end{tabular}

According to the results of the prediction, average values have been proposed for the respective groups of liabilities of the commercial organizations of the Russian Federation studied, wh ich are essential for regulating financial stability in the conditions of the given capital structure and strengthening it in the future. At the same time, it should be mentioned that in case of seeking to achieve the maximum values for $\mathrm{P}_{1}-\mathrm{P}_{5}$, the organizations studied have the opportunity to rebuild the financial stability in current, shortterm and long-term perspective.

\section{CONCLUSION}

In conclusion let us note that from among the options predicted for a particular commercial organization, the management decisions for the $\mathrm{P}_{1}-\mathrm{P}_{5}$ quintiles can be based on the marginal ranges deffering by maximum, minimum and average values, which will allow to accurately assess the efficiency of financial management from the perspecive of organizations in the same industry.

\section{REFERENCES}

[1] J. Williams, "Theory of Investment Value. Cambridge", Mass: Harvard University Press, 1938.

[2] D. Durand, Cost of debt and equity funds for business: trends and problems in measurement, Conference on research in Business Finance. National Bureau of Economic Research. N. Y., 1962, pp. $215-$ 262 .
[3] F. Modigliani, and M. Miller "How much does the firm cost" translated from English". M.: File, 2001, 270 p.

[4] A.V. Arakelyan, "On the formation of favorable capital structure", Armenia, Finance and Economy, Armenia, Finance and Economy, 2007, No 7-8 (84-85), July-August-September, pp. 49-53.

[5] M. La Rocca, T. La Rocca, and A. Cariola, "Capital structure decisions during a firm's life cycle", Small Business Economics, 2011, No. 37, pp. 107-130.

[6] H. Leland, and D. Pyle, Informational asymmetries, financial structure and financial intermediation", Journal of Finance, 1977, Vol. 32, pp. 371-387.

[7] D. Kahneman, and A. Tversky, "Prospect theory: An analysis of decision under risk", Econometrica, 1979, Vol. 47, pp. 313-327.

[8] M. Haire, "Biological models and empirical histories of the growth of organizations", Modern Organization Theory, New York: John Wiley \&amp Sons, Inc., 1959, pp. 272-306.

[9] A. Mahajan, S. Tartaroglu, Equity market timing and capital structure: international evidence, Journal of Banking and Finance, 2008, No. 32, pp. 754-766.

[10] S. Bikhchandani, D. Hirshleifer, and I. Welch, "Learning from the behavior of others: conformity, fads, and informational cascades", The Journal of Economic Perspectives, 1998, Vol. 12, No 3, pp. 151-170.

[11] L. Barros, and A. Silveira, "Overconfidence, managerial optimism and the determinants of capital structure", Working Paper, 2007.

[12] K.A. Hovhannisyan, "The problems concerning security in own current assets of the organization and the affecting factors", Finance and Economy Magazine,2008, no 5(94), pp. 84-87.

[13] A. Mirzoyan, "Liquidity factor assessment approach in alcoholic beverage companies", Finance and Economy, 2018, 8(218), pp. 34-41.

[14] M.G. Matevosyan, and A.V. Matevosyan, "Prediction for security in own current assets in the alcoholic beverage companies of the Republic of Armenia", Future of Science - 2016: Book of Reports of the Third 
International Competition of Scientific Research Works (29 April 2016), Scientific Editor, Doctor of Economics, Professor A.V. Gumerov, Kazan: "Roketa Soyuz” LLC, 2016. pp. 229-234.

[15] D. Kingma, and B. Jimmy, "Adam: A method for stochastic optimizat ion”, ADAM (Adaptive Moment Estimation), 2014, arXiv:1412.6980 [cs.LG].

[16] K. Padachi, "Trends in working capital management and its impact on firms' performance: An analysis of Mauritian small manufacturing firms", International Review of Business Research Papers, 2006, 2(2).

[17] H.P. Dong, and J. Su, "The Relationship between Working Capital Management and Profitability: A Vietnam Case", International Research Journal of Finance and Economics, 2010, Vol. 49.

[18] I. Arbidāne, and S. Ignatjeva, "The Relationship between Working Capital Management and Profitability: a Latvian Case", Research papers "Global Review of Accounting and Finance", 2013, Vol 4, No 1.

[19] I. Welch, Capital structure and stock returns, Journal of Political Economy, 2004, Vol. 112. 